\title{
ASSESSMENT OF COMPOSTING, ENERGY AND GAS GENERATION POTENTIAL FOR MSW AT ALLAHABAD CITY IN INDIA
}

\author{
Sumedha Chakma ${ }^{1}$, Rakesh Chandra Vaishya ${ }^{2}$ \\ ${ }^{1}$ Assistant Professor, ${ }^{2}$ Professor, Civil Engineering Department, Motilal Nehru National Institute of Technology \\ Allahabad,UttarPradesh, India, s_chakma@rediffmail.com,chakma@mnnit.ac.in,rcvaishya@mnnit.ac.in
}

\begin{abstract}
Management of municipal solid waste (MSW) is a major concerned for Allahabad city as the city is growing with population and the increase is 20.74 percent for the last 10 years. In this regard, MSW samples were collected from twenty wards and three dumpsites to estimate composting, energy and gas generation potential for MSW Management. It was observed that the MSW is not suitable for composting because C/N ratio was found to be less than 30:1. Existing gas generation model is modified and found a bioreactor landfill with leachate recirculation would be the best method for the MSW management.
\end{abstract}

Keywords: Municipal solid waste, Energy, Composting, Gas generation, Calorific Value, landfill

\section{INTRODUCTION}

Waste disposal in open area or low lying area are being practised by communities for more than five thousand years [18]. Many Indian cities still considered open dumping as the preferred means of disposing municipal solid waste (MSW) because it is generally the easiest and the cheapest way of dealing the refuse compared to other methods like incineration and composting. But due to urbanization and increase in population from $11 \%$ in 1901 to $26 \%$ in 2001 [8], the cities are facing serious problems of managing its MSW. Although in India, MSW (Management \& Handling) Rules has come into effect in the year 2000 for collection, segregation, storage, transportation, processing and disposal of municipal solid. However, this rules are not being fully implemented at Allahabad city and disposal of MSW is still continues through open dumping [11]. This practice is not only causes an environmental hazard but also an ecological imbalance that leads to land, water and air pollution [12]. The major affects that takes place in and around the dumping sites are methane emission, greenhouse effects, ozone depletion, odours, generation of leachate, settlement due to biodegradation and water pollution $[5 ; 6 ; 7]$.

The production of MSW was 509 ton/day with per capita generation rate $0.52 \mathrm{~kg}$ in 2005 for Allahabad city and expected to reach the generate rate $0.60 \mathrm{~kg} / \mathrm{capita} /$ day in 2012 $[15 ; 16]$. MSW of the city contains $45.3 \%$ organic matter and $40 \%$ inert materials (bricks, fine dust, rubber, wood, leather, etc.). The percentage of recyclable materials (glass, paper plastics, metals etc.) is very low. It is due to rag pickers, who collect and segregate recyclable materials from collection point and disposal sites which are not in big numbers [16]. There is no modern landfill available to manage the MSW and the waste is dumped in a mixed form on open waste land or low lying areas. These days, the most promising technologies for the MSW management are composting, incineration and landfilling. Composting of MSW is the most simple and cost effective technology for treating the organic fraction of MSW which can be determined from $\mathrm{C} / \mathrm{N}$ ratio. Incineration is an efficient way to reduce the waste volume but required heavy investments with high operating costs and suitability can be determined from the calorific value of the MSW. Modern landfilling with leachate recirculation and energy recovery such as bioreactor landfill has also proved good result for MSW management [14].

In the present study various physico-chemical parameters like Carbon, Hydrogen, Oxygen, Nitrogen, Sulphur, along with moisture content and volatile matter (VM) for MSW were analyzed and determined the energy, composting and gas generation potential for the Allahabad city. The outcomes of the analysis were used to suggest the best suitable method of MSW management among energy recovery, composting and landfilling.

\section{STUDY AREA}

\subsection{Study area}

Allahabad, a major city of east Uttar Pradesh State (India), situated at 25.25 North latitude and 81.58 East longitudes. The population was 49, 36, 105 in 2001 and has reached to 59, 59, 798 in 2011 [10]. This shows that city is growing with population and there is an increase in 20.74 percent since 2001. The total area under Allahabad district is about $5481 \mathrm{Sq} \mathrm{km}$. Allahabad Municipal Corporation is responsible for the management of the MSW generated in the city. The city is 
having 80 wards divided into four zones (N, S, E, and W) and six dumpsites. Out of 80 wards and six dumpsites, 20 wards and 3 dumpsites were selected for sample collection as shown in Figure 1. Samplings were carried out during the months of July, 2009 to June 2010 as per international standard [3]. Total five numbers of sampling were carried out during the mention period with equal interval of time. The selection of the source of MSW was predetermined randomly to accommodate all types of sources (i.e. high, medium and low residential households, institutional, commercial and other sources). To carry out the analysis a number of items of equipment like hand protective plastic gloves for handling, scales capable of weighing up to $10 \mathrm{~kg}$, smaller range scales for detailed analysis, $10 \mathrm{~mm}$ thick plastic sheets to cover the floor, plastic bag for collection and sorting of solid wastes, trash bag for collection of already processed wastes, and field observation were used.

\subsection{MSW sample preparation}

Samples collected from different locations were heterogeneous mixtures. The collected samples were segregated on the basis of visual inspection. One of the fractions obtained in the segregation process was a mixture of kitchen/ food waste, plants, and other biodegradable matter referred as compostable matter in this study. The portions of the waste were not taken for the analysis includes metals, glass, rubber, plastics, bones, textiles etc. Polythene bags were used for the collection of wastes. Polythene bags were made air tight to prevent the moisture losses.

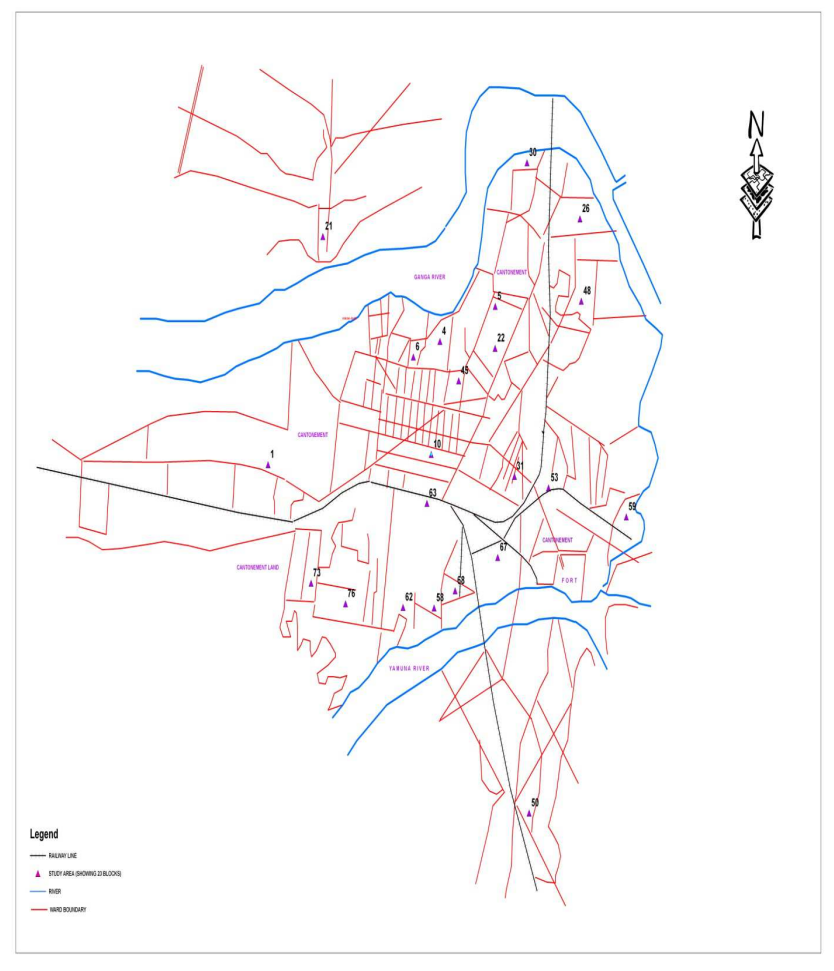

The collected samples were transferred to the laboratory on the day of sampling. It is not possible to remove all the unwanted substances (metals, glass, plastics etc) from the sample on the spot therefore the sample was re-segregated in to the laboratory to remove these substances. To prepare homogeneous mixture of the MSW, samples were then properly mixed with the help of mixer. A properly mixed sample from mixer of $50 \mathrm{~g}$ was taken and oven dried in a constant temperature of $105{ }^{\circ} \mathrm{C}$ for an hour. Grinding of oven dried samples was done with the help of small size mixer to convert it in the powdered form.

\section{METHODOLOGY}

\subsection{Energy Content}

The chemical compositions of the organic matter in MSW such as the percentage of the $\mathrm{C}, \mathrm{H}, \mathrm{O}, \mathrm{N}$ and $\mathrm{S}$ were determine by using CHNS analyzer (Model-Elementary Vario MICRO) as per ASTM E 777-87 \& ASTM778-87 [3]. Calorific value of the MSW was then determined by using Mott and Spooner Model shown [13] as,

Energy Content $(\mathrm{kcal} / \mathrm{kg})$

$=80.3 \mathrm{C}+338.9 \mathrm{H}-3.47 \mathrm{O}+22.49 \mathrm{~S}$

Where $\mathrm{C}=$ Carbon in Percent, $\mathrm{H}=$ Hydrogen in Percent, $\mathrm{O}=$ Oxygen in Percent, $\mathrm{S}=$ Sulfur Percent

Again, on the basis of volatile organic matter (VM) and moisture content $(\mathrm{W})$ the energy content can be obtained by Bento's model [1] as

Energy Content $(\mathrm{kcal} / \mathrm{kg})$

$=44.75 \mathrm{VM}-5.85 \mathrm{~W}+21.2$

\subsection{Gas generation}

Landfill gas generation can be modelled using first order kinetic empirical model to estimate methane gas $[2 ; 17]$ by Eq. 3.

$G=W k L_{0} \exp (-k t)$

Where, $G$ is the rate of methane generation $\left(\mathrm{m}^{3} /\right.$ year $), W$ is mass of solid waste deposited (ton/year), $L o$ is the methane generation potential $\left(\mathrm{m}^{3} /\right.$ ton), and $k$ is the first order kinetic decay constant (1/year), $t$ is time interested for gas generation (year).

US EPA Land GEM model [17] is modified incorporating gas generation with depth (z) as shown in Eq. (4).

$$
G=\sum_{i=1}^{n} \sum_{j=1}^{z} W_{j} k L_{0} \exp \left(-k t_{j, i}\right)
$$

Figure1. MSW Sampling Site 
where, $\mathrm{j}$ is the starting time period of waste disposal, $\mathrm{z}$ is the total number of years for waste disposal (year) with depth, $i$ is the post closure landfill starting period, $n$ is the post closure gas generation period, $\mathrm{Wj}$ is mass of solid waste deposited (ton/year), , and $\mathrm{k}$ is the first order kinetic decay constant (1/year).

\section{RESULTS AND ANALYSIS}

The moisture content in the MSW varies maximum amongst all the compositions ranging from $21.3 \%$ to $39.08 \%$ with an average percentage $27.33 \%$ as depicted in Table 1 . It was observed that the dumpsites and the sites having low collection frequency generally have lower value of the moisture content. The moisture content of the waste collected from commercial areas were observed higher value since regular collection of waste takes place from these areas and also the waste contains high amount of food waste. Similarly, Oxygen content varies from 12.22 to $22.25 \%$ and Carbon varies from $7.33 \%$ to $13.74 \%$ with an average value $12.34 \%$. Solid waste contains less percentage of Hydrogen, Nitrogen and Sulphur and estimated value is less than $1 \%$ for Nitrogen and sulphur; however hydrogen varies from 0.81 to 1.60 with an average value $1.33 \%$ as shown in Table 1.

\subsection{C/N Ratio}

The carbon to nitrogen ratio (C: $\mathrm{N}$ ratio) is the relative percentage of carbon to that of nitrogen in various organic materials. $\mathrm{C} / \mathrm{N}$ ratio is a critical parameter in the design of composting system and should ideally lie between 25 and 50, the optimum value being 25:1 [4]. In present study it was observed that the $\mathrm{C} / \mathrm{N}$ ratio of wastes is not very high. $\mathrm{C} / \mathrm{N}$ ratio in the MSW varies from 16.00 to $24.55 \%$ as depicted in Figure 2 with an average percentage $19.72 \%$. The $\mathrm{C} / \mathrm{N}$ ratio can be adjusted by blending of waste of high $\mathrm{C} / \mathrm{N}$ ratio (e.g. saw dust, paper) with the waste of low $\mathrm{C} / \mathrm{N}$ ratio (e.g. yard waste, raw activated sludge).

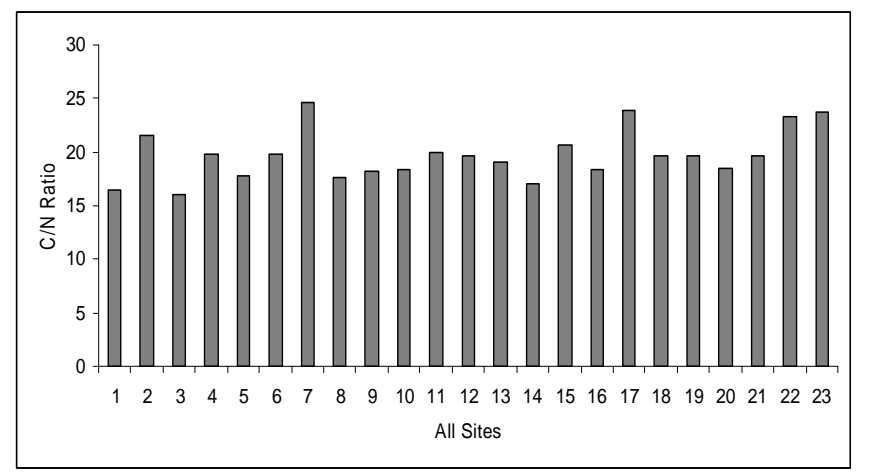

Figure 2 C/N Ratio for all sites

\subsection{Energy content}

The percentage of calorific value present for all the sites is shown in Figure 3. The calorific value of the waste is not very high because of lower percentage of the carbon and higher oxygen content in the waste. It was estimated energy content varies in the range of 2495.60 to $2972.02 \mathrm{kcal} / \mathrm{kg}$ using Eq. (1); however, Eq.(2) estimated using volatile organic content and moisture content lesser energy content and average value was observed as $811.05 \mathrm{kcal} / \mathrm{kg}$. This shows that MSW is not suitable for incineration as minimum recommended value for incineration is $1433 \mathrm{kcal} / \mathrm{kg}$ for any season [19]. However with dried condition, it is possible to use for Incineration.

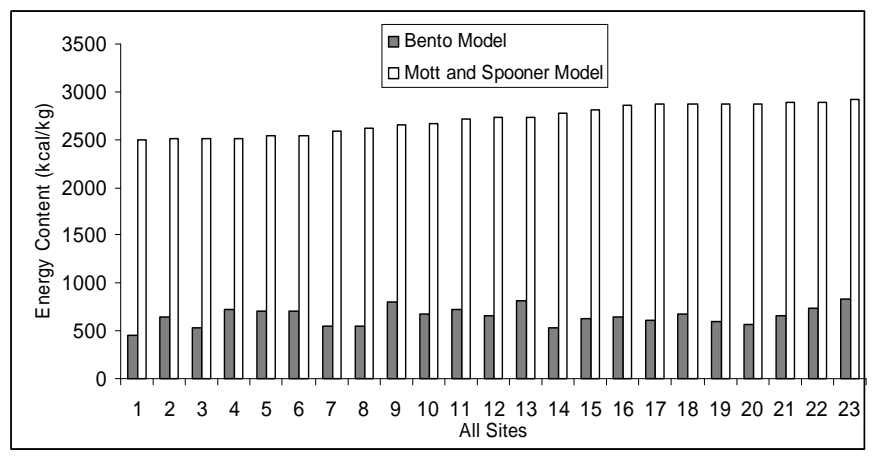

Figure 3 Energy content for all sites

\subsection{Gas generation}

It is assumed twenty years for the closure of the landfill with all the waste generated dumped in landfills. The management of solid waste for Indian condition suggested that it can be made controlled sanitary landfill or bioreactor landfills [14].

The model parameter $L o$ is taken as $170 \mathrm{~m}^{3} /$ ton and $k$ as 0.05 year $^{-1}$ for controlled sanitary landfill while 0.15 for bioreactor landfill with leachate recirculation respectively [9]. $W$ was calculated 16.33 ton/year for the Allahabad city. Methane production rates estimated using Eq. (2) is shown in Figure 4 for controlled and bioreactor landfill with leachate recirculation. It depicts that the gas generation is higher at the initial and during closure of landfill i.e. at the end of 20 years for bioreactor landfills with leachate recirculation compared to controlled sanitary landfills. After 40 years of the closure of landfills, there would be no gas generation for bioreactor landfills whereas gas generation would continue beyond 90 years for controlled sanitary landfills. This shows that bioreactor landfills with leachate recirculation would be beneficial for Allahabad city because it will not only generate energy but also possible to use landfill after 30 to 40 years of closure. 
Table 1: Measured values of C, H, N, S, O, VM and W (\% dry weight)

\begin{tabular}{|l|l|l|l|l|l|l|l|}
\hline Site No. & $\mathbf{C}$ & $\mathbf{H}$ & $\mathbf{N}$ & $\mathbf{S}$ & $\mathbf{O}$ & $\mathbf{V M}$ & $\mathbf{W}$ \\
\hline 1 & 9.22 & 0.95 & 0.56 & 0.20 & 36.10 & 15.64 & 29.09 \\
\hline 2 & 10.25 & 1.08 & 0.48 & 0.21 & 35.18 & 15.47 & 29.33 \\
\hline 3 & 7.33 & 0.81 & 0.46 & 0.19 & 31.82 & 14.65 & 24.09 \\
\hline 4 & 12.95 & 1.50 & 0.65 & 0.23 & 43.34 & 20.49 & 35.20 \\
\hline 5 & 9.55 & 1.07 & 0.54 & 0.19 & 44.66 & 16.97 & 36.42 \\
\hline 6 & 13.74 & 1.60 & 0.69 & 0.18 & 43.96 & 22.18 & 34.68 \\
\hline 7 & 12.67 & 1.25 & 0.52 & 0.21 & 43.03 & 19.33 & 35.46 \\
\hline 8 & 10.97 & 1.23 & 0.62 & 0.19 & 43.97 & 17.79 & 36.39 \\
\hline 9 & 11.78 & 1.28 & 0.65 & 0.20 & 35.42 & 18.37 & 28.44 \\
\hline 10 & 11.19 & 1.28 & 0.61 & 0.18 & 42.68 & 18.53 & 34.63 \\
\hline 11 & 11.31 & 1.23 & 0.57 & 0.20 & 43.72 & 18.71 & 35.37 \\
\hline 12 & 11.26 & 1.26 & 0.57 & 0.21 & 36.65 & 19.27 & 27.54 \\
\hline 13 & 9.65 & 1.15 & 0.50 & 0.20 & 42.05 & 15.97 & 35.03 \\
\hline 14 & 7.68 & 0.96 & 0.45 & 0.20 & 32.65 & 13.20 & 26.60 \\
\hline 15 & 11.63 & 1.38 & 0.56 & 0.25 & 31.86 & 18.36 & 24.57 \\
\hline 16 & 11.34 & 1.23 & 0.62 & 0.20 & 41.38 & 18.02 & 33.96 \\
\hline 17 & 10.25 & 1.19 & 0.43 & 0.19 & 30.83 & 18.12 & 22.82 \\
\hline 18 & 12.23 & 1.44 & 0.62 & 0.23 & 45.30 & 18.07 & 39.08 \\
\hline 19 & 10.53 & 1.16 & 0.53 & 0.18 & 29.47 & 16.82 & 22.54 \\
\hline 20 & 12.93 & 1.55 & 0.70 & 0.26 & 34.94 & 20.82 & 26.68 \\
\hline 21 & 10.55 & 1.22 & 0.54 & 0.24 & 29.92 & 18.33 & 21.30 \\
\hline 22 & 13.47 & 1.34 & 0.58 & 0.20 & 41.92 & 22.25 & 32.08 \\
\hline 23 & 13.19 & 1.40 & 0.56 & 0.22 & 36.47 & 21.37 & 27.71 \\
\hline AVG & 11.12 & 1.24 & 0.57 & 0.21 & 38.14 & 18.21 & 30.39 \\
\hline
\end{tabular}

\section{CONCLUSIONS}

Energy, composting and gas generation potential were studied to suggest the best sustainable method for MSW management. It was observed that MSW for Allahabad city is not suitable for composting because of low $\mathrm{C} / \mathrm{N}$ ratio. However, it is

possible to accomplish incineration in dried form and adding high calorific value material such as plastic. The present scenario suggested that best suitable technique for the sustainable MSW management would be bioreactor landfill with leachate recirculation. Further research can be done to suggest best composting methods by the process of segregation and blending of waste.

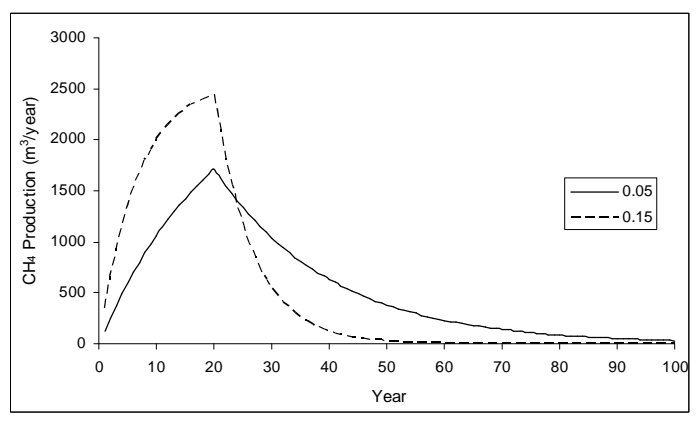

Figure 4 Estimated Methane productions

\section{ACKNOWLEDGEMENTS}

The author is acknowledged Mr. Alok Kumar Yadav for conducting the experiment.

\section{REFERENCES}

[1] Abu-Quadais, M., Abu-Qdais, H. A. (2000) Energy content of municipal solid waste in Jordan and its potential utilization. Energy Conversion and Management, 41, 983-991.

[2] Amini H. R.,Reinhart D. R. and Mackie K. R. (2012). Determination of first-order landfill gas modeling parameters and uncertainties. Waste Management 32, 305-316.

[3] ASTM D 4687-95(2006) \& ASTM D 5231-92(2003), ASTM International, United State.

[4] Central Public Health and Environmental Engineering Organisation (CPHEEO), (2000). Manual on Municipal Solid Waste Management. Ministry of Urban Development, Govt. of India.

[5] Chakma, S. and Mathur, S (2007)a. Leachate: A threat to groundwater contamination at Delhi. International Conference on Water Resource Management: Challenges and Opportunities in the $21^{\text {st }}$ Century, Silchar, Assam, April 23-25. 
[6] Chakma, S. and Mathur, S (2007)b. Modelling gas generation from landfills. Environmental Awareness and Management, 137-142.

[7] Chakma, S. and Mathur, S. (2012). "Post closure longterm settlement for MSW landfills." Journal of Hazardous, Toxic, and Radioactive Waste, ASCE Publication 17(2), 81-88.

[8] Ghose, M. K., Dikshit, A. K., and Sharma, S. K. (2006). A GIS based transportation model for solid waste disposal - A case study on Asansol municipality. Waste Management, 26(11), 1287-1293.

[9] Hossain M.S., Gabr M. A., and Barlaz,M. A. (2003). Relationship of Compressibility Parameters to Municipal Solid Waste Decomposition. Journal of Geotechnical and Geoenvironmental Engineering 129, 1151-1158.

[10] http://www.census2011.co.in/census/district/546allahabad.html.

[11] http://www.cpcb.nic.in/Municipal_Solid_Waste.php

[12] Kansal, A., Prasad, R. K., and Gupta, S. (1998). Delhi municipal solid waste and environment - an appraisal. Indian Journal of Environment Protection 18(2), 123128.

[13] Kathiravale, S., Yunus, M., Sopiahk N., Samsuddin, A. H. 2003. Energy Potential from municipal solid waste in Malaysia. Journal of Renewable Energy, 29, 559-567.

[14] Mathur, S. and Chakma, S. (2003). MSW Management through Bioreactor Landfill", Proc. on Advances in Civil Engineering: Perspectives of Developing Countries, HBTI, Kanpur, Vol.2, 546-552.

[15] NEERI Report. (2005). Assessment of status of municipal solid waste management in metro cities, state capitals, class I cities and class II towns. National Environmental Engineering Research Institute, Nagpur.

[16] Sharholy, M., Ahmad, K., Vaishya, R.C., and Gupta, R.D. (2007). Municipal solid waste characteristics and management in Allahabad. Waste Management, 27, 490-496.

[17] U.S. Environmental Protection Agency (US EPA). (1998). User's manual lanfill gas emissions: Model version 2.0. EPA/600/R-98/054, Research Triangle Park, N.C.

[18] White-Hunt., K. (1980). Domestic Refuse - A brief History. Solid Waste, 70, 609.

[19] World Bank (1999). Technical Guidance Report on Municipal Solid Waste Incineration. The World Bank Washington, DC.

\section{BIOGRAPHIES}

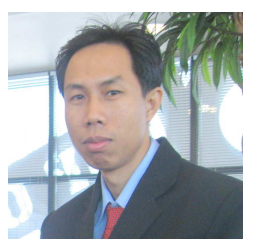

Dr. Sumedha Chakma did his Ph.D. from Indian Institute of Technology Delhi. His research fields are solid waste management, settlement in landfills, bioreactor landfills, and infiltration studies. He has more than 25 research publications.

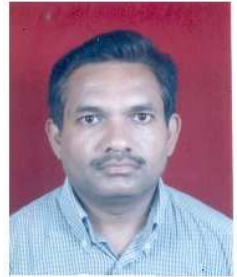

Dr. Rakesh Chandra Vaishya did his $\mathrm{Ph} . \mathrm{D}$. from Indian Institute of Technology Bombay. His research fields are solid waste management, air pollution, environmental impact assessment, and rural water supply. He has more than 50 research publications. 